\title{
Mullitization kinetics from silica- and alumina-rich wastes
}

\author{
S.C. Vieira, A.S. Ramos, M.T. Vieira* \\ ICEMS, Department of Mechanical Engineering, Coimbra University Polo II, R. Luís Reis Santos, 3030-201 Coimbra, Portugal \\ Received 21 February 2005; received in revised form 24 March 2005; accepted 29 July 2005 \\ Available online 19 September 2005
}

\begin{abstract}
Mullite was produced from a mixture of raw wastes with high contents of silica and aluminium hydroxides. The first were wastes from slate rocks and had muscovite, chlorite and quartz as their main crystalline phases. The second were aluminium sludges resulting from the physicochemical treatment of the wastewaters generated by aluminium surface treatment industries. As-received raw materials were weighed to produce the 2:1 alumina:silica stoichiometric mixture, corresponding to an excess of alumina relatively to the ideal 3:2 mullite composition. The nonisothermal activation energies for primary $(431 \mathrm{~kJ} / \mathrm{mol})$ and secondary mullite crystallization $(454 \mathrm{~kJ} / \mathrm{mol})$ were determined by differential dilatometry. Sintered products were composites of mullite and $\alpha$-alumina dispersed in a glassy phase and presented flexural strengths higher than $100 \mathrm{MPa}$ after sintering temperatures at $1285^{\circ} \mathrm{C}$.
\end{abstract}

(C) 2005 Elsevier Ltd and Techna Group S.r.l. All rights reserved.

Keywords: B. Microstructure-final; B. Microstructure-prefiring; D. $\mathrm{Al}_{2} \mathrm{O}_{3}$; D. Mullite

\section{Introduction}

Through the years a wide range of mullite-forming precursors has been used to prepare either mullite or mullite-rich ceramics, therefore influencing mullite purity and homogeneity, and mullitization temperatures have been reported to differ largely depending on the synthesis methods $[1,2]$. Mullitization temperature is clearly dependent on the degree of mixing of aluminium and silicon in the precursors, and natural mullite precursors like aluminium silicate minerals, were recognized to be advantageous for the production of mullite because $\mathrm{Al}_{2} \mathrm{O}_{3}$ and $\mathrm{SiO}_{2}$ are mixed on a molecular scale in them [3]. Several works showed that in spite of being a very rare mineral in nature, mullite is a very common reaction product of most aluminium silicates at high temperatures [4]. In fact, aluminium silicate systems like pure clays and clay-aluminium hydroxide or clay-aluminium oxide mixtures have been extensively used to produce mullite ceramics, with special attention being paid to kaolin-based mixtures [5-15]. Kaolinite and kaolinite-based ceramic formulations mullitization behaviour has been studied with the purpose of producing not only mullite-rich products [6$7,10,12-15]$ but also other classes of high-technology ceramics

\footnotetext{
* Corresponding author. Tel.: +351 239790700; fax: +351 239790701.

E-mail address: teresa.vieira@dem.uc.pt (M.T. Vieira).
}

[5]. In spite of the work accomplished, it is still difficult to present a concise reaction sequence for kaolinite due to the complexities involved in its phase transformation and microstructural evolution at elevated temperature, and to its susceptibility to modifications related to structural or impurities variations [8,10]. Pask and Tomsia [8] studied kaolinite phase evolution till $1300{ }^{\circ} \mathrm{C}$ and found that both mullite and spinel phase have the possibility to form concurrently at about $980{ }^{\circ} \mathrm{C}$. Later work by Chen et al. [10] referred that the formation either of spinel phase or of silicon-containing $\gamma$-alumina at $980{ }^{\circ} \mathrm{C}$ is still under debate and reported the formation of mullite only above $1100{ }^{\circ} \mathrm{C}$. Chen et al. [13] identified the formation of mullite at $1006.5^{\circ} \mathrm{C}$ and claimed that the discrepancy relative to the $980{ }^{\circ} \mathrm{C}$ reported by other authors might have been due to a different kaolin sample having somewhat different impurities or particle size distribution of the starting materials. The nonisothermal activation energy of mullite crystallization in kaolin ceramics was $1182.3 \mathrm{~kJ} / \mathrm{mol}$, with an associated growth morphology parameter $(n)$ of about 2 , related to bulk nucleation and two-dimension diffusion-controlled growth of plate-like mullite crystals [13]. By studying the effect of the addition of alumina to kaolinite, Liu and Thomas [6] and Liu et al. [7] found that at temperatures below or equal to $1300{ }^{\circ} \mathrm{C}$ there was a limited reactivity between kaolinite and $\alpha$-alumina, leaving $\alpha$-alumina grains largely inert and forming primary mullite crystals with a narrow size distribution. At temperatures equal 
or higher than $1400{ }^{\circ} \mathrm{C}$, the reactivity increased thus leading to the progressive decrease of $\alpha$-alumina XRD peaks, which were no longer present after sintering at $1600{ }^{\circ} \mathrm{C}$. Besides the primary mullite crystals, nucleated from kaolinite, smaller secondary mullite crystals, formed through a solution-precipitation mechanism via a transient liquid phase, were observed. Chen et al. [12] also pointed out the primary mullite formation between 1000 and $1300{ }^{\circ} \mathrm{C}$ (isothermal activation energy $=1356.9 \mathrm{~kJ} / \mathrm{mol}, n=1.9)$ and the secondary mullite formation in the $1300-1600{ }^{\circ} \mathrm{C}$ temperature range $(1164.6 \mathrm{~kJ} / \mathrm{mol}, n=1.2)$.

Meanwhile, some authors investigated the possibility of using other natural mullite precursors besides clay materials. In fact, recent studies on the production of mullite rich-ceramics from aluminium silicate minerals focused the recovery of wastes from dimensional stones exploitation facilities, namely slate wastes $[16,17]$. Slate waste powders have been submitted to thermal treatments under several atmospheres and using different heating velocities [18]. X-ray diffraction studies showed no phase transformation up to $730{ }^{\circ} \mathrm{C}$, when the powders were heated at $10{ }^{\circ} \mathrm{C} / \mathrm{min}$ in static air atmosphere. Above this temperature the presence of talc was identified and at $800{ }^{\circ} \mathrm{C}$ the presence of olivine was detected. Traces of hercynite were present at $950{ }^{\circ} \mathrm{C}$ and mullite, hematite and glassy phase were identified at $1050{ }^{\circ} \mathrm{C}$. Apparent activation energy for mullite formation was calculated from non-isothermal differential thermal analysis $\left(E_{\mathrm{a}}=490 \mathrm{~kJ} / \mathrm{mol}\right)$, and instantaneous nucleation followed by diffusion-controlled growth mechanism resulted in tabular mullite crystals [18]. Results concerning the addition of $\gamma$ alumina to slate waste powders showed a general increase in the mullite content, especially when longer sintering times were employed. The mollies growth rate was controlled by the dissolution of the alumina particles in the glassy phase and subsequent reaction with silica, instead of the diffusioncontrolled mechanism observed for slate wastes only [16].

Besides alumina polymorphs, aluminium hydroxides have also been used as alumina sources in aluminium silicate-based mullite-forming mixtures $[14,15,17]$. The aluminium hydroxides were either obtained during bauxite refining processes or synthesized from aluminium salts, but also by-products from aluminium industry, namely aluminium sludges produced by physico-chemical treatment of wastewater generated by electrochemical treatment of aluminium surfaces [17,19]. These aluminium sludges are mainly composed by water (7585 wt.\%) and colloidal aluminium hydroxides. The presence of sodium or calcium (generated from neutralising solutions) and aluminium sulphates (used as flocculating agent) [20,21], and some minor elements like iron, copper, zinc, tin, silicon and magnesium, have also been reported. The characterization of this kind of sludges revealed their strong shrinkage behaviour $[19,22]$ and their particle fineness $[19,20]$. The high content of alumina in heat-treated aluminium sludges acted as a drivingforce for the attempts of re-use them as a raw material in the ceramic industry $[17,20,22,23]$. The addition of this kind of sludges to slate wastes resulted in mullite- $\alpha$-alumina composites and an important increase of mullite content (secondary mullite) was observed, simultaneously with a significant decrease of silica phases [17].

In the present work, a $2: 1\left(\mathrm{Al}_{2} \mathrm{O}_{3}: \mathrm{SiO}_{2}\right.$ ratio $)$ mixture has been prepared from the addition of aluminium sludges to slate wastes and subsequently reaction-sintered to produce mullite. Primary mullite resulted from slate wastes decomposition, while secondary mullite resulted from reaction of the aluminium sludges with the slate wastes. Phase evolution was investigated using X-ray diffraction and apparent activation energies for the phase transformations were calculated from non-isothermal dilatometric experiments. Physico-chemical characterization of the sintered products was also performed.

\section{Experimental details}

\subsection{Sample preparation and characterization}

Slate wastes (Empresa Lousas de Valongo, Lda, Valongo, Portugal) and as-received aluminium-rich sludges (Tecnilaca, Mem-Martins, Portugal) were used as raw materials to prepare an alumina-silica mixture with $\mathrm{Al}_{2} \mathrm{O}_{3}: \mathrm{SiO}_{2}$ ratio of $2: 1$. Accordingly to the reported elsewhere [18], the main phases in the slate waste powders were muscovite, chlorite and quartz, therefore providing the mixture both with silica and alumina (Table 1). As-received aluminium sludges were mainly formed by aluminium oxides/hydroxides and water, and their chemical composition was evaluated through atomic absorption spectroscopy and gravimetry (Table 2) after drying at $110{ }^{\circ} \mathrm{C}$. Sulphate ions and constitutional water (hydroxyl groups), not removed by low-temperature thermal treatment, are mainly responsible for the other $\sim 38 \mathrm{wt} . \%$.

In order to prepare the alumina-silica mixture with the required 2:1 $\mathrm{Al}_{2} \mathrm{O}_{3}: \mathrm{SiO}_{2}$ ratio, as-received aluminium sludges were sieved through a $4-5 \mathrm{~mm}$ sieve, mixed with water and agitated at $5500 \mathrm{rpm}$, until a consistent and uniform pulp was formed. The required amount of slate waste was added and mixing was performed using a turbomixer at $6000 \mathrm{rpm}$ for $60 \mathrm{~s}$. The pulp was then filter-pressed, deagglomerated, dried at 105$110{ }^{\circ} \mathrm{C}$, and sieved below $1 \mathrm{~mm}$. The resulting powders were calcined to $900{ }^{\circ} \mathrm{C}$, deagglomerated through a $250 \mu \mathrm{m}$ sieve, and then uniaxially or cold isostatically pressed. Uniaxially pressed samples $(72 \mathrm{~mm} \times 13 \mathrm{~mm} \times 5 \mathrm{~mm})$ were sintered in air using a muffle type furnace (heating/cooling rate: $5^{\circ} \mathrm{C} / \mathrm{min}$, holding time: $30 \mathrm{~min}$, sintering temperatures: 1000 to $1300{ }^{\circ} \mathrm{C}$ ).

Table 1

Chemical composition and loss on ignition (LOI) of slate waste powders

\begin{tabular}{|c|c|c|c|c|c|c|c|c|c|c|c|c|}
\hline & \multicolumn{11}{|l|}{ Oxide } & \multirow[t]{2}{*}{ LOI } \\
\hline & $\mathrm{SiO}_{2}$ & $\mathrm{Al}_{2} \mathrm{O}_{3}$ & $\mathrm{Fe}_{2} \mathrm{O}_{3}$ & $\mathrm{FeO}$ & $\mathrm{CaO}$ & $\mathrm{MgO}$ & $\mathrm{Na}_{2} \mathrm{O}$ & $\mathrm{K}_{2} \mathrm{O}$ & $\mathrm{TiO}_{2}$ & $\mathrm{MnO}$ & $\mathrm{P}_{2} \mathrm{O}_{5}$ & \\
\hline wt. $\%$ & 53.30 & 24.03 & 1.42 & 7.37 & 0.34 & 20.8 & 1.64 & 3.06 & 0.89 & 0.07 & 0.23 & 5.57 \\
\hline
\end{tabular}


Table 2

Dried aluminium sludges chemical composition

\begin{tabular}{llllllll}
\hline & \multicolumn{2}{l}{ Specie } & & & & & \\
\cline { 2 - 7 } & $\mathrm{Al}_{2} \mathrm{O}_{3}$ & $\mathrm{Fe}$ & $\mathrm{S}$ & $\mathrm{Na}$ & $\mathrm{Ca}$ & $\mathrm{Zn}$ & $\mathrm{Cr}$ \\
\hline wt.\% & 55 & 0.15 & 4.6 & 1.20 & 0.30 & 0.07 & 0.23
\end{tabular}
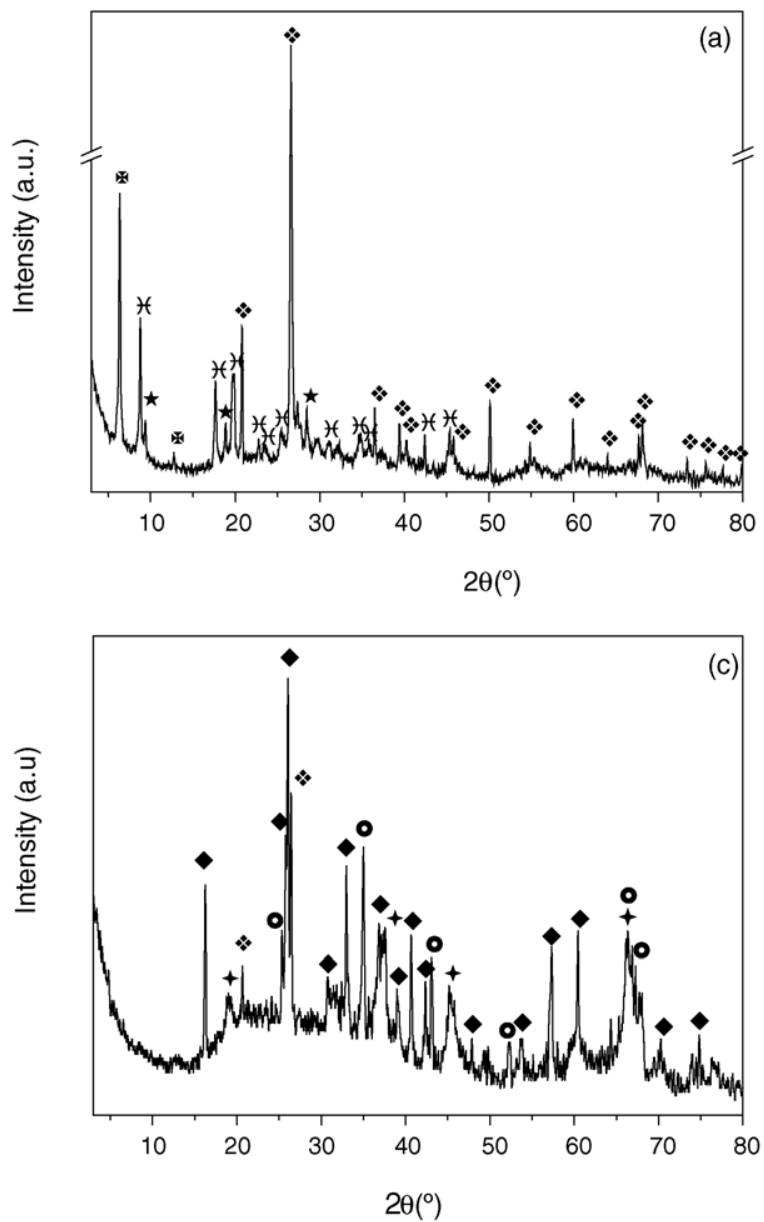

Cold isostatic pressing was used to prepare samples for thermodilatometric experiments.

Sintered samples were characterized by shrinkage calculation, density determination (conventional water displacement method), X-ray diffraction (Rigaku difractometer with copper anode), and leaching [24] and three-point bend tests [25].
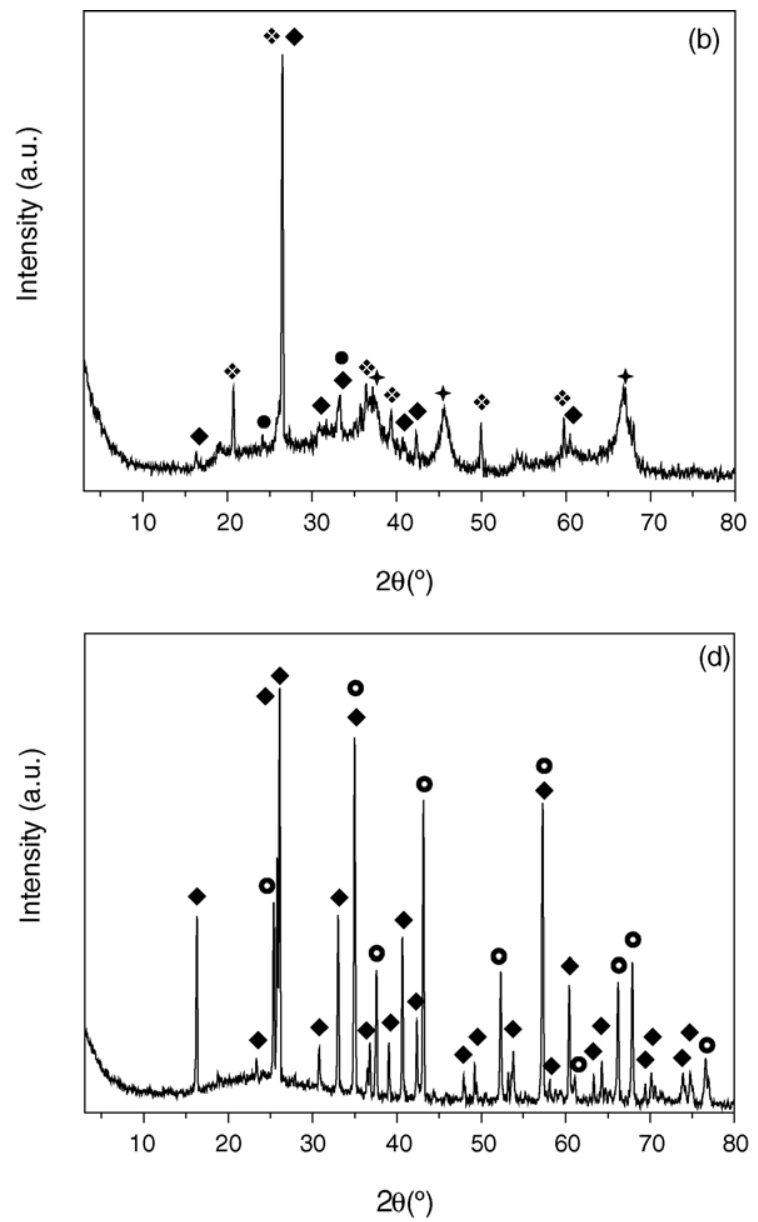

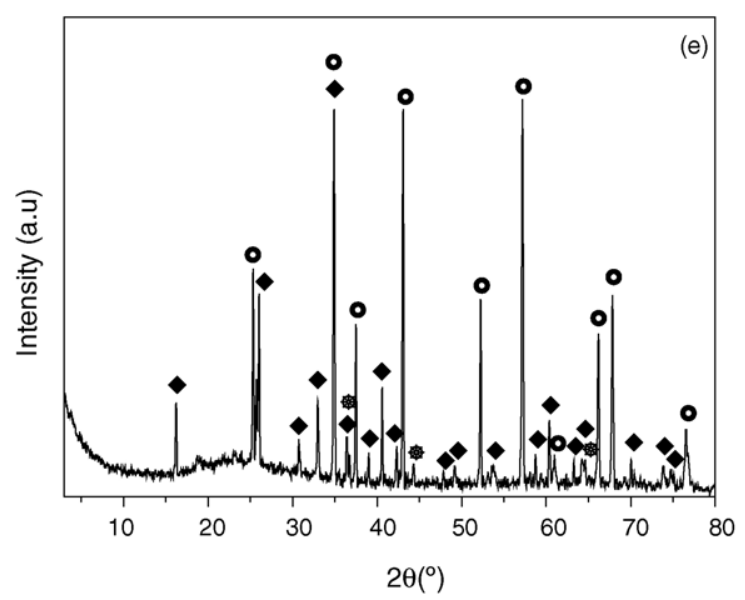

Fig. 1. X-ray diffraction patterns of the slate waste-aluminium sludge mixtures (a) calcined powders and pressed bodies sintered at (b) 1000, (c) 1170 , (d) 1250 and

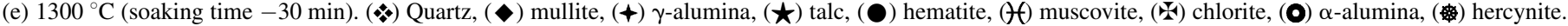




\subsection{Thermodilatometric study}

Thermodilatometric study was performed over cold isostatic pressed (ciped) samples using a NETZSCH DIL 402ED differential dilatometer. Samples were heated under a primary vacuum atmosphere using variable heating rates $(1,5$ and $\left.10^{\circ} \mathrm{C} / \mathrm{min}\right)$. Phase transformations in heat-treated samples were followed by X-ray diffraction (Philips X'Pert difractometer with cobalt anticathode, $45 \mathrm{kV}, 35 \mathrm{~mA}$ ). Reaction kinetics were studied from dilatometric behaviour of the samples.

\section{Results and discussion}

\subsection{Phase development}

Muscovite and quartz are the main phases in as-prepared powders of the aluminium sludge-slate waste mixtures $\mathrm{Al}_{2} \mathrm{O}_{3}: \mathrm{SiO}_{2}=2: 1$ (Fig. 1(a)). Minor phases, like chlorite, talc, olivine and feldspar, resulting from slate wastes composition [18], are also present. As also observed for chlorite by other authors [26-28], and namely for the thermal treatment of slate wastes by themselves [18], during the thermal treatment an increase in intensity of the $\left(\begin{array}{lll}0 & 0 & 1\end{array}\right)$ diffraction peak and a concomitant decrease of the remaining reflections occurred.

After sintering at $1000{ }^{\circ} \mathrm{C}$ for $30 \mathrm{~min}$, quartz is the only crystalline phase in common with the as-prepared mixture (Fig. 1(b)). Mullite, hematite and $\gamma$-alumina are the newly formed phases. Both mullite (primary mullite) and hematite result from slate wastes phase evolution with temperature. Besides hercynite spinel-type phase, and contrarily to what occurs for the heat treatment of other natural mullite precursors, such as kaolinite $[9,13]$, in the temperature range from 900 to $1000{ }^{\circ} \mathrm{C}$, there is no evidence for formation of $\mathrm{Al}-\mathrm{Si}$ or $\mathrm{Al}$ spinel phases in slate wastes. Therefore, $\gamma$-alumina must result exclusively from aluminium sludge phase evolution [19]. It was difficult to determine whether $\gamma$-alumina was already present in the powders pre-treated at $900{ }^{\circ} \mathrm{C}$ or not, due to its small crystal size and poor crystallinity, along with the dissolution effect produced by the addition of slate waste powders to Al-rich sludge.

On increasing sintering temperature hematite disappears and mullite reflections become more pronounced. Below $1100{ }^{\circ} \mathrm{C}$ aluminium sludge-slate waste mixtures are largely inert and the dominant reactions are those observed in slate wastes and aluminium sludges reaction series separately. However, at $1170{ }^{\circ} \mathrm{C}$ (Fig. 1(c)) and above an increase of mullite X-ray diffraction peaks occurs associated with formation of secondary mullite from the reaction of silica-rich phases with $\gamma$ alumina from the aluminium sludge. $\alpha$-Alumina is clearly identified in samples sintered at $1170{ }^{\circ} \mathrm{C}$ and coexists with $\gamma$ alumina, which disappears at $1200{ }^{\circ} \mathrm{C}$. For kaolinite- $\alpha$-alumina mixtures $[6,12]$, it was obvious that mullite peaks became more pronounced at the expense of $\alpha$-alumina, confirming that mullite formation and $\alpha$-alumina reaction proceeded concurrently. In opposition, the dependence of secondary mullite formation on the alumina source consumption is not so obvious

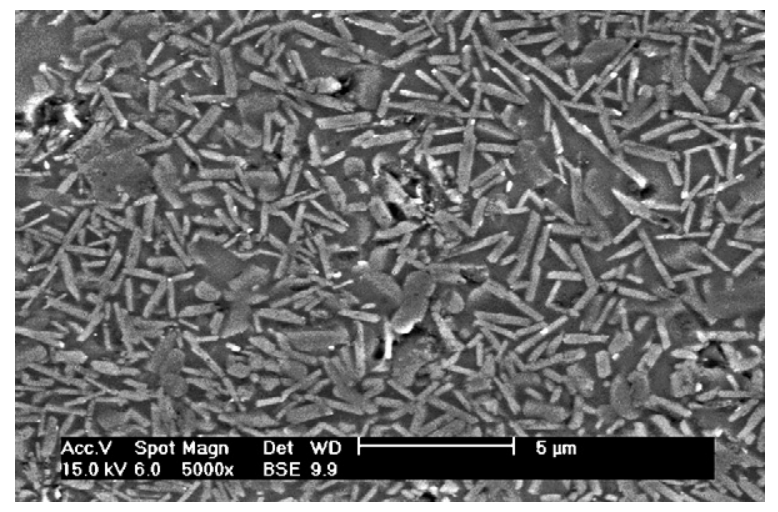

Fig. 2. Scanning electron microscopy image of the final sintered product.

in the present waste mixtures, once the aluminium hydroxides in the aluminium sludges have to thermally transform to $\alpha$ alumina through $\gamma$-alumina as the sintering temperature increased. The transformation between alumina polymorphs takes place in the same temperature range as the secondary mullite formation, therefore disturbing a quantitative interpretation of $\gamma$ reaction as a function of the increase of mullite quantity in the sintered samples. At $1200{ }^{\circ} \mathrm{C}$ a strong increase of the intensity of mullite diffraction peaks occurs and a slight broadening of the $\left(\begin{array}{lll}1 & 3 & 0\end{array}\right)$ peak $(d=2.4280 \AA)$ of mullite is observed, related to the appearance of the well defined hercynite $\left(\begin{array}{lll}3 & 1 & 1\end{array}\right)$ peak $(d=2.4597 \AA)$ for higher sintering temperatures (Fig. 1(d)). At the maximum sintering temperature, $1300{ }^{\circ} \mathrm{C}$ (Fig. 1(e)), mullite and $\alpha$-alumina are the main crystalline phases in the sintered body, whose microstructure is presented in Fig. 2. The final sintered body consists in plates and needles embedded in a glassy phase (Fig. 2). It should be noticed that unlike observations for other aluminosilicatealumina mixtures $[14,15]$, and in spite of the $2: 1 \mathrm{Al}_{2} \mathrm{O}_{3}: \mathrm{SiO}_{2}$ ratio used in the slate waste-aluminium sludge mixtures, only $3: 2$ mullite has been identified in sintered test bodies. The excess of $\mathrm{Al}_{2} \mathrm{O}_{3}$ appeared in the form of either $\gamma$ - or $\alpha$-alumina.

Hercynite is still present at $1300{ }^{\circ} \mathrm{C}$, together with some glassy phase. Between 1250 and $1300{ }^{\circ} \mathrm{C}$ a not fully understood decrease of mullite reflections is observed. The presence of impurities in aluminium hydroxides has been suggested as a driving-force for the dissolution of primary mullite in clayalumina systems and the enhancement of the formation of secondary mullite [15]. In the present study, the alkali impurities in the waste materials will give rise to fluid and corrosive silicate liquids likely to dissolve mullite and be responsible for the apparent overall decrease of mullite content in the sintered body.

\subsection{Kinetic study}

Cold isostatic pressed samples were submitted to preliminary heating experiments in order to determine the phase transformation temperature ranges under non-isothermal heating (heating rate: $10{ }^{\circ} \mathrm{C} / \mathrm{min}$ ). X-ray diffraction patterns in Fig. 3 show that quartz, muscovite and $\gamma$-alumina are the crystalline phases identified after reheating the sample to 


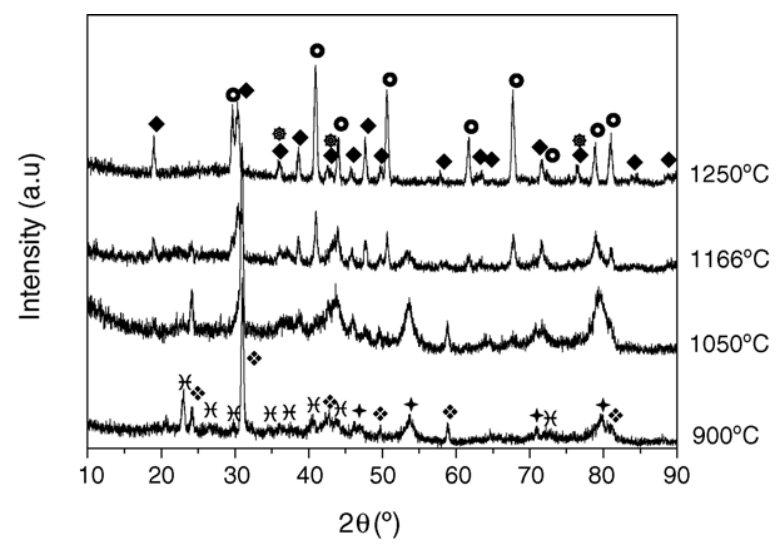

Fig. 3. X-ray diffraction patterns of dilatometric test bodies submitted to nonisothermal heating experiments. $(*)$ Quartz, $(\diamond)$ mullite, $(\boldsymbol{\star}) \gamma$-alumina, $(\boldsymbol{C})$ muscovite, (O) $\alpha$-alumina, hercynite.

$900{ }^{\circ} \mathrm{C}$. Increasing the temperature to $1050{ }^{\circ} \mathrm{C}$ leads to a decrease of the intensity of the quartz and muscovite reflections, and to the appearance of mullite (primary mullite). Between 1050 and $1166{ }^{\circ} \mathrm{C}$ muscovite disappears. Simultaneously, with the reduction of quartz and $\gamma$-alumina peaks, there is an increase in the mullite peaks (secondary mullite formation) and a new crystalline phase appears: $\alpha$-alumina. At the maximum temperature, $1250{ }^{\circ} \mathrm{C}$, mullite, $\alpha$-alumina and also hercynite are identified. Both $\gamma$-alumina and crystalline silica are no longer present at this temperature, but there is enough evidence to confirm the presence of silica in glassy form (extremely broad reflection in the $20^{\circ}-30^{\circ} 2 \theta$ range). Further dilatometric experiments, using heating rates of 1, 5 and $10{ }^{\circ} \mathrm{C} / \mathrm{min}$ (Fig. 4), were therefore employed in the evaluation of the activation energy involved in the mixture phase transformations that gave origin successively to primary and secondary mullite, and $\alpha$-alumina.

The activation energies for the phase transformations of the 2:1 aluminium sludge-slate waste mixtures were determined by a non-isothermal method assuming the following equation [29]:

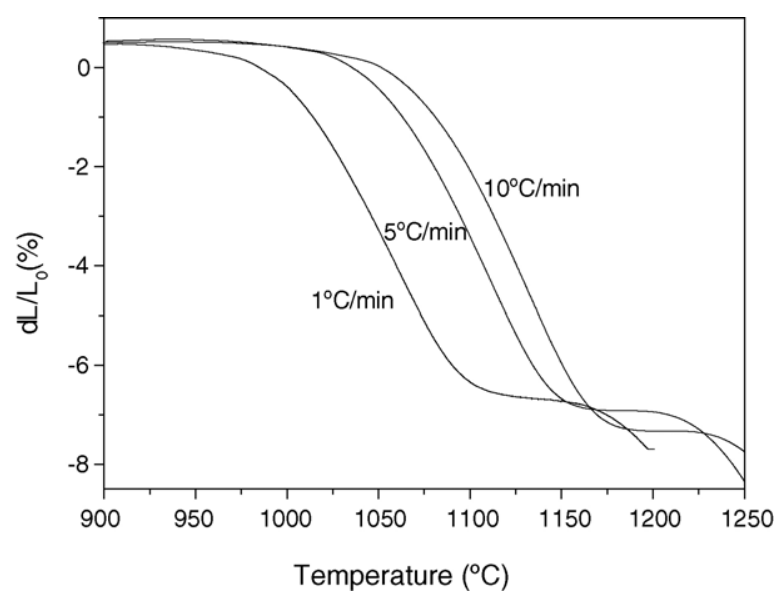

Fig. 4. Dilatometric curves for the slate waste-aluminium sludge mixtures ciped bodies heating for different heating rates: 1,5 and $10^{\circ} \mathrm{C} / \mathrm{min}$.
Table 3

Peak temperatures at the reaction maxima for each heating rate

\begin{tabular}{cccc}
\hline Heating rate $\left({ }^{\circ} \mathrm{C} / \mathrm{min}\right)$ & $T_{\mathrm{m}_{1}}\left({ }^{\circ} \mathrm{C}\right)$ & $T_{\mathrm{m}_{2}}\left({ }^{\circ} \mathrm{C}\right)$ & $T_{\mathrm{m}_{3}}\left({ }^{\circ} \mathrm{C}\right)$ \\
\hline 1 & 993 & 1017 & 1059 \\
5 & 1044 & 1069 & 1110 \\
10 & 1064 & 1086 & 1130 \\
\hline
\end{tabular}

$\ln \left(\frac{\phi}{T_{\mathrm{m}}^{2}}\right)=-\frac{E_{\mathrm{a}}}{R T_{\mathrm{m}}}+C_{1}$

Here, $\phi$ is the heating rate, $T_{\mathrm{m}}$ is the absolute temperature at the maximum of the reaction, $E_{\mathrm{a}}$ is the activation energy, $R$ is the gas constant, and $C_{1}$ is a constant. When the left side of Eq. (1), $\ln \left(\phi / T_{\mathrm{m}}^{2}\right)$, is plotted against $1 / T_{\mathrm{m}}$, the activation energy $E_{\mathrm{a}}$ can be calculated from the slope of the straight line.

The temperatures at the reactions maxima (Table 3) were determined by fitting to the first derivative of the thermodilatometric curves and the activation energies under vacuum were calculated from the plots of $\ln \left(\phi / T_{\mathrm{m}}^{2}\right)$ versus $1 / T_{\mathrm{m}}$ (Fig. 5). The activation energy for primary mullite formation $(431 \mathrm{~kJ} / \mathrm{mol})$ is slightly lower than that for secondary mullite formation $(454 \mathrm{~kJ} / \mathrm{mol})$. These results counteract those of Chen et al. [12] for the kaolin- $\alpha$-alumina system, where it was found that the unreacted alumina powder dispersed in the ceramic reduced the degree of homogeneity of $\mathrm{Al}^{3+}, \mathrm{Si}^{4+}$ and $\mathrm{O}^{2-}$ components in the raw material mixture, relatively to that observed in kaolinite, therefore resulting in higher activation energy for primary mullite formation. Both primary and secondary mullite formation activation energies reported by these authors are significantly higher than those obtained in the present slate-sludge mixtures. Also, through the years values of the activation energy for mullite crystallization in kaolin ceramics as different as 350-550 kJ/mol [30] or $1182.3 \mathrm{~kJ} / \mathrm{mol}$ [13] have been reported, thus emphasizing that different activation energy values are associated not only with different crystallization processes but also with differences in the experimental conditions employed for $E_{\mathrm{a}}$ determination [13]. Therefore, the discrepancy in the energies involved in the reactions of the kaolin or slate-based systems do not depend only on the presence or absence of $\alpha$-alumina in the raw materials, which is considered the critical factor in determining the reactions occurring in the $\mathrm{Al}_{2} \mathrm{O}_{3}-\mathrm{SiO}_{2}$ system [31], but also on the aluminosilicates source employed and on the overall preparation methods and experimental conditions. Nevertheless, the non-isothermal activation energies for primary and secondary mullite formation in Valongo slate-aluminium sludge mixtures are in the range determined by Gualtieri et al. [30] (kaolinite-to-mullite reaction sequence): $350-550 \mathrm{~kJ} / \mathrm{mol}$, as also verified for mullite crystallyzation for Valongo slates only $(490 \mathrm{~kJ} / \mathrm{mol})[18]$, being close to that of the isothermal mullitization of single-phase aluminosilicate gels (362 $\pm 145 \mathrm{~kJ} / \mathrm{mol})$ [3].

The activation energy for the formation of $\alpha$-alumina from $\gamma$-alumina $(477 \mathrm{~kJ} / \mathrm{mol})$ in the waste mixtures is lower than that 

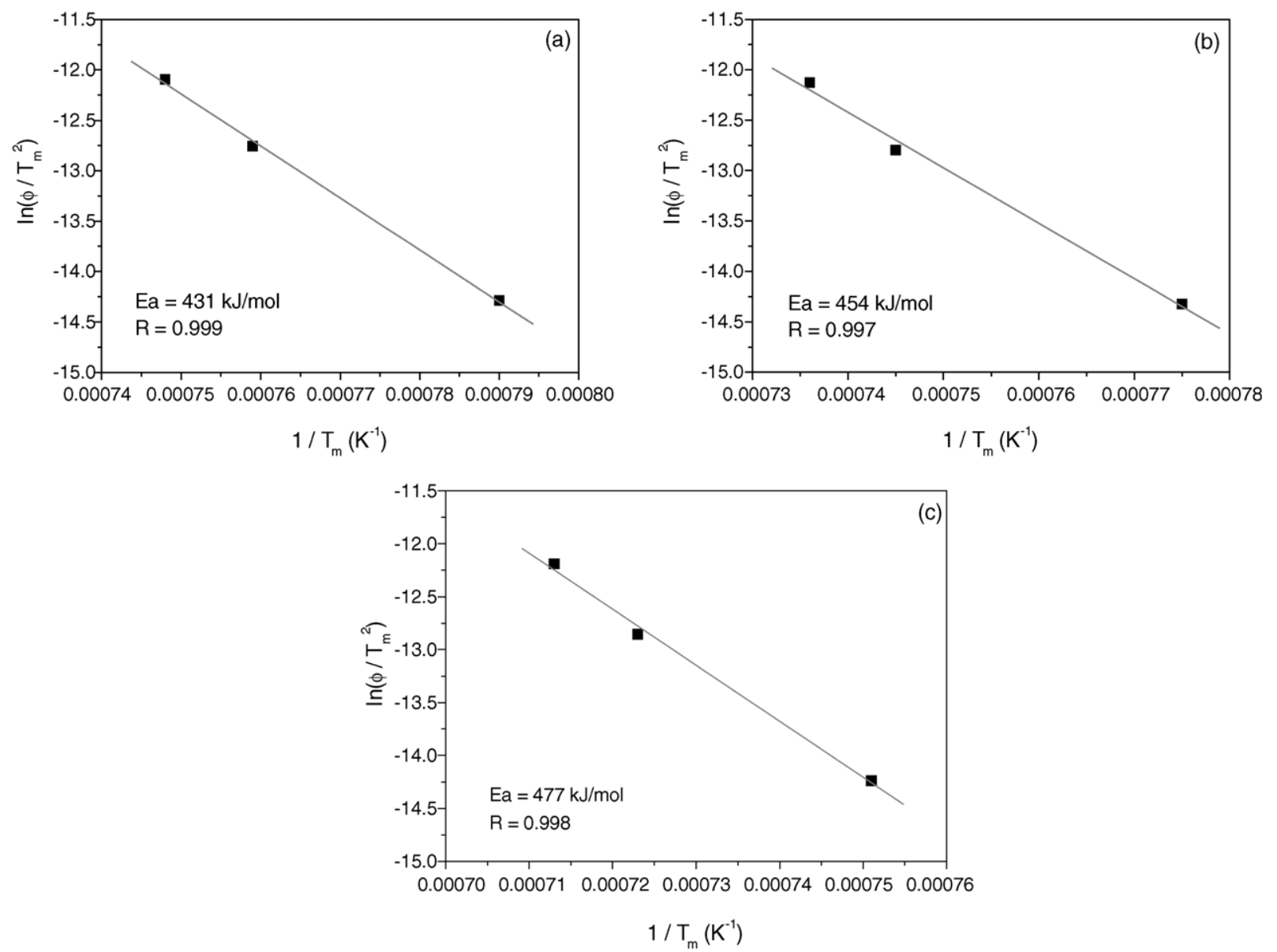

Fig. 5. Plots of $\ln \left(\phi / T_{\mathrm{m}}^{2}\right)$ vs. $1 / T_{\mathrm{m}}$ for determination of the activation energy for the formation of (a) primary mullite, (b) secondary mullite and (c) $\alpha$-alumina in the waste mixture.

reported by Ma and Krell [32], and also lower than that calculated for aluminium sludges $(517 \mathrm{~kJ} / \mathrm{mol})$ [33].

The kinetic description of a process is strongly dependent on the experimental conditions and the ambiguity that inescapably accompanies the interpretation of kinetic data produced from thermal analysis measurements and the risk of misinterpretation largely increases in the presence of highly complex reactive systems [34], like the present rock powder-aluminium sludge mixtures. The activation energy alone is not enough to characterize the reaction kinetics [34]. Nevertheless, in spite of the computational methods already developed to deal with the kinetic study of overlapping isothermal phase transformations [35], using the dilatometric method, it was not possible to determine other kinetic parameters besides activation energy. The large overlap of the temperature ranges for the three phase transformations during the non-isothermal thermomechanical analysis hindered determination of kinetic parameters, such as the growth morphology parameter $n$. For overlapping transformations some authors have attempted to deconvolute the master curves into their components but the physical meaning of such fitting parameters is still under debate [35]. Therefore, kinetic parameters shall not be regarded as intrinsic properties of the solid [34] and the differences between the activation energies determined for the formation of primary and secondary mullite, and $\alpha$-alumina must be analysed keeping in mind that those energies are representative for the particular raw materials and experimental conditions employed.

\subsection{Sintered products characterization}

Table 4 shows the results from physical and mechanical characterization of the 2:1 aluminium sludge-slate waste mixture uniaxially pressed and sintered for $30 \mathrm{~min}$ at temperatures ranging from 1170 to $1300{ }^{\circ} \mathrm{C}$.

Calcining the slate waste-aluminium sludge mixture powders at $900{ }^{\circ} \mathrm{C}$ prior to uniaxial pressing, led to low green density of the pressed samples which is mainly responsible for high porosity $(>5 \%)$, resulting in high water absorption, low density and low strength values for samples sintered at lower temperatures (Table 4). By increasing the sintering temperature the densification is improved, therefore progressively eliminating the porosity and leading to products with lower water absorption, and higher shrinkage and strength values.

The maximum strength (126 MPa) was determined for the densest sample $\left(2.94 \mathrm{~g} / \mathrm{cm}^{3}\right)$, obtained after 30 min sintering at $1300{ }^{\circ} \mathrm{C}$. In fact, the strength values determined for the mullite/ $\alpha$-alumina composites, obtained by sintering the slate waste-aluminium sludge mixtures between 1250 and 
Table 4

Properties of the sintered uniaxially pressed bodies as function of sintering temperature

\begin{tabular}{|c|c|c|c|c|}
\hline & \multicolumn{4}{|c|}{ Sintering temperature $\left({ }^{\circ} \mathrm{C}\right)$} \\
\hline & 1170 & 1250 & 1285 & 1300 \\
\hline Shrinkage $(\%)$ & $13.01 \pm 0.12$ & $25.84 \pm 0.65$ & $30.96 \pm 0.40$ & $33.36 \pm 0.35$ \\
\hline Weight loss (\%) & $12.8 \pm 0.5$ & $13.3 \pm 0.5$ & $12.3 \pm 0.2$ & $12.3 \pm 0.2$ \\
\hline Density & $1.32 \pm 0.02$ & $2.13 \pm 0.05$ & $2.69 \pm 0.05$ & $2.94 \pm 0.01$ \\
\hline Flexure modulus (MPa) & 9 & 67 & 113 & 126 \\
\hline Weibull modulus & 9 & 8 & 11 & 9 \\
\hline Water absorption (\%) & 39.5 & 10.2 & 2.4 & $\sim 0$ \\
\hline Leaching tests & Not dangerous & Inert & Inert & Inert \\
\hline
\end{tabular}

$1300{ }^{\circ} \mathrm{C}$, are higher than those reported for sintered samples produced either from slate powders $(28 \mathrm{MPa})$ or slate $/ \gamma$ alumina powder mixtures (37-43 MPa) [16]. Even the strength values reported by Viswabaskaran et al. [15] for mixtures of calcined clays with aluminium hydroxides are as low as 29$38 \mathrm{MPa}$, for sintered products produced from raw mixtures containing boehmite, or $90-99 \mathrm{MPa}$, for those containing gibbsite, in spite of fully conversion of the samples to mullite. Yet, the strength values calculated in this study are much lower than those obtained by Ohira et al. [36] (300-400 MPa) and Osedin and Baudín [37] (180-220 MPa) for mullite ceramics produced by sintering of high purity mullite powders.

The weight loss is similar for all the sintering experiments and it is most likely due to the presence of thermally stable sulphate species in the aluminium sludges, which decompose to sulphur oxides above $900{ }^{\circ} \mathrm{C}$.

The leaching tests, performed according to the DIN 38414 standard [24], allow the sintered products to be classified as inert for sintering temperatures above $1170{ }^{\circ} \mathrm{C}$. The products sintered at $1170{ }^{\circ} \mathrm{C}$ have to be classified as not-dangerous due to a $\mathrm{Cr}$ content slightly higher than that allowed for inert materials [38].

\section{Conclusions}

Slate wastes and aluminium sludges were used to prepare a mixture with an $\mathrm{Al}_{2} \mathrm{O}_{3}: \mathrm{SiO}_{2}$ ratio of $2: 1$. The mixture was investigated using characterization techniques such as $\mathrm{X}$-ray diffraction and thermodilatometry. The results of the present study are summarized as follows:

1. The addition of aluminium sludges to slate wastes leads to an increase of mullite content in the sintered product, due to the reaction between $\gamma$-alumina and silica.

2 . The temperature of the primary mullite formation in the mixture is close to that observed in slate wastes and the nonisothermal activation energy for primary mullite crystallization is $368 \mathrm{~kJ} / \mathrm{mol}$.

3. The temperature and activation energy values for secondary mullite formation are much lower than the ones reported for other mullite-forming systems.

4. The composition of the mixture and the kinetics of the phase transformations lead to a final sintered product composed of mullite and $\alpha$-alumina embedded in a glassy phase.
5. Fully densified products with high flexural strength were obtained through $30 \mathrm{~min}$ sintering at maximum temperature $\left(1300{ }^{\circ} \mathrm{C}\right)$.

\section{Acknowledgment}

This work was supported by Fundação para a Ciência e Tecnologia, under contract POCTI/35500/CTM/2000.

\section{References}

[1] H. Schneider, K. Okada, J.A. Pask, Mullite and Mullite Ceramics, John Wiley \& Sons, England, 1994.

[2] A. Souto, F. Guitian, Purification of mullite by reduction and volatilization of impurities, J. Am. Ceram. Soc. 82 (10) (1999) 2660-2664.

[3] D.X. Li, W.J. Thomson, Mullite formation kinetics of a single-phase gel, J. Am. Ceram. Soc. 73 (4) (1990) 964-969.

[4] I.A. Aksay, D.M. Dabs, M. Sarikaya, Mullite for structural, electronic, and optical applications, J. Am. Ceram. Soc. 74 (10) (1991) 2343-2358.

[5] K. Mackenzie, R. Meinhold, I. Brown, G. White, The formation of mullite from kaolinite under various reaction atmospheres, J. Eur. Ceram. Soc. 16 (1996) 115-119.

[6] K.-C. Liu, G. Thomas, Time-temperature-transformation curves for kaolinite- $\alpha$-alumina, J. Am. Ceram. Soc. 77 (6) (1994) 1545-1552.

[7] K-C. Liu, G. Thomas, A. Caballero, J.S. Moya, S. Aza, Mullite formation in kaolinite- $\alpha$-alumina, Acta Metall. Mater. 42 (2) (1994) 489-495.

[8] J.A. Pask, A.P. Tomsia, Formation of mullite from sol-gel mixtures and kaolinite, J. Am. Ceram. Soc. 74 (10) (1991) 2367-2373.

[9] S. Lee, Y.J. Kim, H.-S. Moon, Phase transformation sequence from kaolinite to mullite investigated by an energy-filtering transmission electron microscope, J. Am. Ceram. Soc. 82 (10) (1999) 2841-2848.

[10] C.Y. Chen, G.S. Lan, W.H. Tuan, Microstructural evolution during the sintering of kaolin powder compacts, Ceram. Int. 26 (2000) 715-720.

[11] C.Y. Chen, W.H. Tuan, The processing of kaolin powder compact, Ceram. Int. 27 (2001) 795-800.

[12] Y.-F. Chen, M.-C. Wang, M.-H. Hon, Transformation kinetics for mullite in kaolin- $\mathrm{Al}_{2} \mathrm{O}_{3}$ ceramics, J. Mater. Res. 118 (6) (2003) 1355-1362.

[13] Y.-F. Chen, M.-C. Wang, M.-H. Hon, Phase transformation and growth of mullite in kaolin ceramics, J. Eur. Ceram. Soc. 24 (8) (2004) 23892397.

[14] V. Viswabaskaran, F.D. Gnanam, B. Balasubramanian, Mullitisation behaviour of south Indian clays, Ceram. Int. 28 (5) (2002) 557-564.

[15] V. Viswabaskaran, F.D. Gnanam, B. Balasubramanian, Mullitisation behaviour of calcined clay-alumina mixtures, Ceram. Int. 29 (2003) $561-571$.

[16] I.M. Martins, J. Sousa, L. Catarino, M.T. Vieira, M.M. Oliveira, The formation of mullite from rock wastes containing alumina and silica, Key Eng. Mater. 230-232 (2002) 380-383.

[17] I.M. Martins, S. Vieira, V. Livramento, J. Sousa, F. Delmas, M.M. Oliveira, M.T. Vieira, Manufacture of ceramic products using inertized aluminium sludges, Mat. Sci. Forum 455-456 (2004) 822-826. 
[18] L.M. Catarino, Xistos ardosíferos: caracterização e recuperação de desperdícios, Ph.D. thesis, University of Coimbra, Portugal, 1999.

[19] S. Vieira, M.T. Vieira, L. Catarino, Recovery of sludges from aluminum surface treatments, in: Proceedings of the TMS Fall 2002 Extraction and Processing Division Meeting on Recycling and Waste Treatment in Mineral and Metal Processing: Technical and Economic Aspects, 2002, pp. 489-498.

[20] M.J. Ribeiro, D.U. Tulyaganov, J.M. Ferreira, J.A. Labrincha, Recycling of Al-rich industrial sludge in refractory ceramic pressed bodies, Ceram. Int. 28 (2002) 319-326.

[21] A.P. Oliveira, V. Gomes, D. Hotza, O. Montedo, R. Picoli, F. Pereira, Aluminium rich sludge as raw material for the ceramic industry, Interceram 52 (1) (2003) 44-47.

[22] A. Seabra, D. Pereira, C. Bóia, J. Labrincha, Pre-treatment needs for the recycling of Al-rich anodising sludge as a ceramic raw material, in: Proceedings of the 1st Latin American Clay Conference, 2000, pp. 176-181.

[23] D.A. Pereira, D.M. Couto, J.A. Labrincha, Incorporation of alumina rich residues in refractory bricks, Ceram. Forum Int. 77 (7) (2000) 21-25.

[24] DIN Standard 38414 Part 4, October 1984: Sludge and sediments. Determination of leachability by water.

[25] ASTM Standard B 528-76: Standard Test Method for Transverse Rupture Strength of Sintered Metal Powder Specimens.

[26] G.W. Brindley, S.Z. Ali, X-ray study of thermal transformations in some magnesian chlorite minerals, Acta Crystalographica 3 (1950) 25-30.

[27] W.R. Phillips, A differential thermal study of the chlorites, Mineral. Mag. 33 (260) (1963) 404-414.

[28] T. Bai, S. Guggenheim, S. Wang, D. Rancourt, A. Groos, Metastable phase relations in chlorite- $\mathrm{H}_{2} \mathrm{O}$ system, Am. Mineralogist 78 (1993) 1208-1216.
[29] H.G. Wang, H. Herman, X. Liu, Activation energy for crystal growth using isothermal and continuous heating processes, J. Mater. Sci. 25 (1990) 2339-2343.

[30] A. Gualtieri, M. Belloto, G. Artiolli, S.M. Clark, Kinetic study of the kaolinite-mullite reaction sequence. Part II. Mullite formation, Phys. Chem. Minerals 22 (4) (1995) 215.

[31] J.A. Pask, Importance of starting materials on reactions and phase equilibria in the $\mathrm{Al}_{2} \mathrm{O}_{3}-\mathrm{SiO}_{2}$ system, J. Eur. Ceram. Soc. 16 (1996) 101-108.

[32] H. Ma, A. Krell, Synthesis and processing of nano- $\alpha-\mathrm{Al}_{2} \mathrm{O}_{3}$ powders, Key Eng. Mater. 206-213 (2002) 43-46.

[33] Project POCTI/35500/CTM/2000, Final Technical Report, November 2003.

[34] M. Maciejewski, Computational aspects of kinetic analysis. Part B. The ICTAC Kinetics Project-the decomposition kinetics of calcium carbonate revisited, or some tips on survival in the kinetic minefield, Thermochim. Acta 355 (2000) 145-154.

[35] E. Morales, N. Alvarez, J. Leiva, L. Castellanos, C. Villar, R. Hernandez, Kinetic theory of the overlapping phase transformations: case of the dilatometric method, Acta Materialia 52 (2004) 1083-1088.

[36] H. Ohira, M. Ismail, Y. Yamamoto, T. Akiba, S. Somiya, Mechanical properties of high purity mullite at elevated temperatures, J. Eur. Ceram. Soc. 16 (1996) 225-229.

[37] M.I. Osendi, C. Baudín, Mechanical properties of mullite materials, J. Eur. Ceram. Soc. 16 (1996) 217-224.

[38] Portuguese Government Legislation: Decreto Lei no. 152/2002, de 23 de Maio, Diário da República-I Série-A, no. 119, pp. 4680-4698. 